Токарева Уляна Дмитрівна аспірант Донецького державного університету управління, вул. Карпінського, 58, м. Маріуполь, 87500, тел.: (097) 783-73-11, e-mail: ulianatokarieva@gmail.com, https://orcid.org/0000-00033919-5661

\title{
МЕТОДОЛОГІЧНІ ЗАСАДИ ДОСЛІДЖЕННЯ БЕЗБАР'ЄРНОГО СЕРЕДОВИЩА В ПУБЛІЧНОМУ УПРАВЛІННІ
}

Анотація. Визначено, що створення та функціонування безбар'єрного середовища $\epsilon$ важливим напрямом публічного управління, який передбачає співпрацю держави 3 організаціями та ініціативами, які опікуються вирішенням конкретних проблем безбар'єрності.

Доведено, що наявність бар'єрів у різних сферах суспільно-політичного, економічного, культурного життя потребує активної протидії дискримінації та досягнення реальної рівності всіх громадян.

На основі аналізу показників Індексу соціальної мобільності визначено, що слабка інклюзивність інститутів в Україні має розглядатися як одна 3 найбільш актуальних проблем теорії та практики публічного управління стосовно повноцінного, безбар'єрного доступу до освіти, зайнятості, отримання адміністративних послуг держави, безперешкодного життєвого середовища у публічному просторі, доступу до інфраструктурних об'єктів, реалізації права на громадську, політичну участь.

Доведено, що вирішення проблем безбар'єрності в українському суспільстві потребує як стратегічних, так і оперативних управлінських рішень, які мають прийматися на загальнодержавному, місцевому, галузевому рівні, у громадському секторі.

Відмічено, що забезпечення доступності має засновуватися на принципах універсального дизайну. Оцінка стану доступності вимагає комплексного і універсального підходу. Прийняття Національної стратегії зі створення безбар'єрного простору в Україні до 2030 року (2021) розглядається як важливий крок побудови в країні інклюзивного суспільства.

Обгрунтовано важливість створення інклюзивного суспільства, що потребує зусиль не лише з боку держави, але й розширення участі та залучення громадянського суспільства до процесу прийняття рішень, що дозволить забезпечити підзвітність державних структур і підвищити транспарентність в процесах прийняття державних стратегій та рішень.

Ключові слова: безбар'єрність, публічне управління. доступність, розумне пристосування, універсальний дизайн.

Tokareva Ulyana Dmytrivna Postgraduate Student of Donetsk State University of Management, Karpinskoho St., 58, Mariupol, 87500, tel.: (097) 783-73-11, e-mail: ulianatokarieva@gmail.com, https://orcid.org/0000-0003-3919-5661 


\title{
METHODOLOGICAL PRINCIPLES OF RESEARCH OF A BARRIER- FREE ENVIRONMENT IN PUBLIC ADMINISTRATION
}

\begin{abstract}
In the article it is determined that the creation and functioning of a barrier-free environment is an important area of public administration, which involves the cooperation of the state with organizations and initiatives that address specific issues of inclusion.
\end{abstract}

It has been proved that the existence of barriers in various spheres of sociopolitical, economic and cultural life requires active counteraction to discrimination and achievement of real equality of all citizens.

Based on the analysis of the indicators of the Social Mobility Index, it is determined that the weak inclusion of institutions in Ukraine should be considered as one of the most pressing problems of theory and practice of public administration regarding full, inclusive access to education, employment, state administrative services, access to infrastructure, realization of the right to public and political participation.

It is proved that solving the problems of inclusion in Ukrainian society requires both strategic and operational management decisions, which must be made at the national, local, sectoral level and in the public sector.

It is noted that ensuring inclusion should be based on the principles of universal design. Assessing the status of accessibility requires a comprehensive and universal approach. The adoption of the National Strategy for Creating an Inclusive Space in Ukraine (2021) is seen as an important step in building an inclusive society in the country.

The importance of creating an inclusive society is justified and it requires efforts not only on the part of the state, but also by increasing the participation and involvement of civil society in the decision-making process, which will ensure accountability of state structures and increase transparency in state strategies and decisions.

Keywords: inclusion, public administration, accessibility, universal design.

Постановка проблеми. Створення та функціонування безбар'єрного середовища є важливим напрямом публічного управління, який засновується на інклюзивному діалозі 3 представниками цільових груп, 3 залученням організацій громадянського суспільства. Слід зазначити, що до цільових груп наразі залучають не тільки осіб 3 функціональними порушеннями працездатності та інвалідністю, а й людей старшого віку, матерів 3 дітьми до 6 років, дітей, що залишилися без батьківського піклування, молодь, представників національних меншин, міграційних спільнот. Ознаками нерівності можуть бути: соціально-майновий статус, раса, сексуальна орієнтація, стать, релігійні або політичні переконання, інвалідність, мова тощо.

За останні роки проблематика безбар'єрного доступу розглядається як на міжнародному рівні, про що свідчать рішення $\mathrm{OOH}$ (Конвенція ООН про права осіб з інвалідністю (2006), Конвенція про ліквідацію всіх форм 
дискримінацій по відношенню до жінок), європейські ініціативи Європейська соціальна хартія, Стратегія Ради Європи про права осіб 3 інвалідністю на 2017-2023 роки, міжнародна ініціатива рівних прав та можливостей для всіх «Партнерство Біарріц» та інші, так і на національному рівні, зокрема 14 квітня 2021 року в Україні прийнята Національна стратегія iз створення безбар'єрного простору в Україні на період до 2030 року. Філософія нових підходів до безбар'єрності засновується на повазі до прав людини, соціокультурного розмаїття, рівних можливостей та створенні життєздатного суспільства для всіх. Вплив цих ідей на публічне управління передбачає необхідність розробки відповідних методологічних засад для розвитку теорії і практики діяльності публічної влади у цій сфері.

Аналіз останніх досліджень та публікацій. Проблематика дослідження безбар'єрності як об’єкта публічного управління почала розглядатися в останні роки в роботах таких авторів як О.Дрюма, С.Зубченко, О.Зубчик, Ю.Каплан, Л.Смельяненко, О.Роговський, Ю.Тищенко, О.Шульга, О.Царькова, К. Сахарова та інші, але невирішеними питаннями залишаються уточнення принципів, функцій публічної влади у створенні безбар'єрного середовища, механізми створення безбар'єрного простору в окремих напрямах, передбачених Національною стратегією зі створення безбар'єрного простору в Україні до 2030 року, що зумовлює необхідність наукового аналізу цих питань та розробки практичних рекомендацій для органів публічної влади у цій сфері.

Мета статті: аналіз методологічних засад дослідження безбар'єрного середовища в публічному управлінні та визначення основних напрямів діяльності органів публічної влади для його створення та розвитку в Україні.

Виклад основного матеріалу. Безбар'єрність як актуальне питання суспільного життя є важливим напрямом публічної політики, якому в останні роки стали приділяти значну увагу на законодавчому та організаційному рівні.

Україна ратифікувала Конвенцію ООН про права осіб з інвалідністю та у 2020 р. стала учасницею міжнародного проєкту «Партнерство Біарріц», яке започатковане лідерами країн Групи семи (G7) - Канадою, Францією, Німеччиною, Італією, Японією, Великою Британією, США 3 метою консолідації зусиль у забезпеченні гендерної рівності, досягнення рівних прав і можливостей у суспільстві та відсутності обмежень за будь-якими ознаками. У рамках проєкту «Партнерство Біарріц» Україна взяла на себе зобов'язання у п'яти сферах:

доступність публічного простору, сприятливого для сімей $з$ дітьми та маломобільних груп населення;

освіта дітей щодо рівності прав чоловіків і жінок;

запобігання насильству;

забезпечення рівності в оплаті праці чоловіків і жінок;

створення сприятливих умов для підвищенні ролі чоловіків у піклуванні про дітей.

На даний час щодо безбар’єрності в Україні діють такі нормативно- 
правові акти як: Закон України «Про внесення змін до деяких законів України про освіту щодо організації інклюзивного навчання» від 5 червня 2014 року № 1324-VII.; Закон України від 16.01.2020 № 473-IX «Про внесення змін до Закону України «Про регулювання містобудівної діяльності» щодо посилення захисту осіб 3 інвалідністю та інших маломобільних груп населення при здійсненні містобудівної діяльності»; Указ Президента України «Про підвищення ефективності заходів у сфері прав осіб з інвалідністю» від 3 грудня 2019 року № 875/2019. Безумовно, важливим стратегічним документом $є$ Національна стратегія зі створення безбар'єрного простору в Україні до 2030 року, прийнята 14 квітня 2021 року [1].

У відповідності до Конвенції про права осіб з інвалідністю в Україні було введено посади Уповноваженого з прав людей з інвалідністю: в 2014 р. був призначений Уповноважений президента України, а в 2017 р. створена посада Урядового уповноваженого з прав людей з інвалідністю.

Наразі така практика поширюється на місцевому рівні, місто Київ, першим серед міст України, ввів посаду Уповноваженого 3 прав людей 3 інвалідністю. Уповноважений має забезпечувати здійснення Київською міською радою конституційних повноважень щодо забезпечення додержання прав і законних інтересів людей з інвалідністю, в тому числі, які отримали інвалідність в зоні проведення антитерористичної операції, інвалідів війни [2].

Також створено Раду безбар'єрності як консультативно-дорадчий орган при Кабінеті Міністрів, який проводитиме моніторинг виконання передбачених заходів, розробки та реалізації програм, звітуватиме про виконання цільових показників у створенні безбар'єрного середовища, до якого входитимуть представники уряду, місцевого самоврядування, громадянського суспільства, експерти та науковці.

Для оцінки публічної політики щодо безбар'єрності наразі використовується Індекс соціальної мобільності Всесвітнього економічного форуму, який враховує десять факторів, серед яких - здоров'я, освіта, доступ до технологій, можливість працевлаштування, умови праці й справедлива зарплата, соціальний захист та інклюзивність. За рейтингом Індексу соціальної мобільності 2020 р. Україна розташувалася в другій половині таблиці на 46 місці, набравши 61,2 бала. Країна відстає, наприклад, від Румунії (42 місце), Польщі (30 місце). Найбільше Україна відстає по частині інклюзивності інститутів (79 місце), доступу до технологій (64 місце) i постійного навчання (55 місце) [3].

Слабка інклюзивність інститутів в Україні, відображена у показниках Індексу соціальної мобільності, свідчить про необхідність подолання викликів щодо можливостей для різних маломобільних груп та громадян 3 особливими потребами стосовно повноцінного, безбар'єрного доступу до освіти, зайнятості, отримання адміністративних послуг держави, безперешкодного життєвого середовища у публічному просторі, доступу до інфраструктурних об’єктів тощо. Це може стосуватися доступності реалізації 
права на громадську, політичну участь, особливо для людей з інвалідністю та старшого віку, забезпечення безбар'єрного доступу до сфери культури, туризму тощо.

Особливо актуальними ці проблеми є для численної групи людей 3 інвалідністю, яких, за даними Міністерства соціальної політики України, станом на 01 січня 2020 року, налічується в Україні 2,7 млн. осіб, у тому числі 222,3 тис. осіб 3 I групою інвалідності, 900,8 тис. осіб 3 II групою інвалідності, 1416,0 тис. осіб 3 III групою інвалідності та 163,9 тис. [4].

У 2020 р. Київський міжнародний інститут соціології провів перше в Україні соціологічне дослідження щодо ставлення українців до безбар'єрності та інклюзії в суспільстві з метою з'ясувати, з якими бар'єрами стикаються українці, які 3 них найбільш негативно впливають на якість життя [5].

За результатами дослідження. 56\% респондентів оцінили рівень інклюзії в Україні як низький або дуже низький. 77\% вважають вирішення проблем, пов'язаних 3 інклюзією та безбар'єрністю, актуальними для України. На думку учасників опитування, потребам всіх категорій українців у повній мірі не відповідають ключові сфери: інфраструктура (65\%), освіта (45\%), працевлаштування (69\%). Говорячи про психологічні бар'єри, учасники вказують на низький рівень культури поведінки та знань про інклюзію, нерозуміння потреб людей з інвалідністю, людей з обмеженою мобільністю, фізичними чи ментальними відмінностями До найпоширеніших бар'єрів в інфраструктурі респонденти відносять: відсутність зручних маршрутів для маломобільних груп населення (40\%, 3 них 19\% вважають проблему невідкладною), бюрократію (40\% і 25\% відповідно), відсутність понижень і пандусів (37,5\% і 19\%), непристосований громадський транспорт $(21,7 \%)$ [5].

Топ бар'єрів у галузі освіти: упереджене ставлення з боку інших дітей до дітей 3 особливими освітніми потребами (24\%, 3 них $13 \%$ називають проблему невідкладною), відсутність пандусів і ліфтів (22\% 12\% відповідно), складнощі інтеграції спеціальних програм для дітей з вадами зору, слуху, тощо (20\% і 9\%), упереджене ставлення з боку батьків інших дітей (20\% i 9\%), відсутність спеціальних програм для навчання дітей 3 ментальними відмінностями (19\% і 8,5\%), булінг (12,5\%), харчування, що не враховує потреби дітей (11,3\%) тощо. Загалом 74\% респондентів вважають актуальним створення безбар'єрного середовища в закладах освіти [5].

Основними бар’єрами у сфері працевлаштування респонденти вважають: неготовність роботодавців брати на роботу людей 3 інвалідністю та людей старшого віку (58\% та 53,5\%), відсутність або недостатню кількість обладнаних робочих місць для людей 3 інвалідністю $(51,5 \%)$, упереджене ставлення до людей 3 інвалідністю 3 боку роботодавців і колег (28\%), відсутність сервісів пошуку роботи та перекваліфікації для людей старшого віку $(39,4 \%)$ тощо. На думку 69\% респондентів, сфера працевлаштування у їхньому населеному пункті не є безбар'єрною [5].

Наведені дані свідчать про серйозність проблематики безбар'єрності в 
українському суспільстві практично у всіх сферах, що не може надалі залишатися у такому стані і потребує як стратегічних, так і оперативних управлінських рішень, які мають прийматися на загальнодержавному, місцевому, галузевому рівні, у громадському секторі.

Найбільшою цільовою групою, яка потребує забезпечення безбар'єрності, можна вважати людей з інвалідністю. О.Дрюма, досліджуючи цю проблематику, виділив п'ять основних проблем, які потребують відповідних управлінських рішень:

1) якісна доступність інфраструктури, особливо, що стосується інфраструктури об’єктів приватного сектору,

2) комплексна доступність об'єкту,

3) відсутність інформації (інформаційних покажчиків) про наявність / відсутність умов доступності об’єктів інфраструктури для людей 3 інвалідністю,

4) створення доступної транспортної та вуличної інфраструктури,

5) недостатність громадського контролю державної політики у сфері створення безбар'єрного середовища [6].

Погоджуючись 3 автором, вважаємо, що для цієї цільової групи слід додати такі проблеми як:

1. Покращення доступу до конкурентної зайнятості для людей 3 інвалідністю, зокрема забезпечення рівних прав чоловіків та жінок 3 інвалідністю.

2. Покращення доступу до медичних послуг для людей 3 інвалідністю, зокрема для жінок та дітей з інвалідністю.

3. Усунення перешкод у наданні послуг людям 3 інвалідністю шляхом підтримки місцевих ініціатив 3 універсального дизайну товарів, послуг, інфраструктури та інформації.

4. Проведення інформаційної кампанії 3 питань інвалідності, доступності та універсального дизайну серед ключових зацікавлених сторін та широкої громадськості.

Вищеназвані проблеми визначають необхідність впровадження при прийнятті управлінських рішень в першу чергу концепції доступності, пов'язаної 3 різними потребами і функціональними можливостями користувачів. Коли Україна у 2009 р. ратифікувала Конвенцію про права інвалідів, вона взяла на себе зобов'язання щодо «універсального дизайну» та «доступності», що означають, відповідно, «дизайн предметів, оточення, програм та послуг, покликаний зробити їх максимально придатними до користування усіма людьми без необхідності у адаптації або спеціального дизайну» та - «рівний доступ до фізичного оточення, транспорту, інформації та зв'язку, зокрема інформаційно-комунікаційних технологій i систем, а також до інших об'єктів і послуг, відкритих або таких, що надаються населенню, як у міських, так і в сільських районах» [7].

Універсальний дизайн не виключає допоміжних пристроїв для конкретних груп осіб з інвалідністю, де це необхідно (розміщення вхідних площадок, сходів і підйомних пристроїв та їх захисту від атмосферних 
опадів; шляхів руху маломобільних відвідувачів усередині будинку; доступність механізмів управління, команд або даних, що дають змогу всім користувачам сприймати, розуміти інформаційні дані тощо).

Створення доступного середовища забезпечує та гарантує всім однакові права, поліпшує якість життя, надає більше незалежності та свободи для реалізації своїх життєвих цілей, створює готове до змін прогресивне, гуманне суспільство. Це означає, що оцінка стану доступності в такому розумінні вимагає комплексного і універсального підходу і прийняття Національної стратегії зі створення безбар’єрного простору в Україні до 2030 року (2021) [1] розглядається нами як важливий крок побудови в Україні доступного суспільства.

Очікуваними результатами реалізації Стратегії мають стати «безперешкодний доступ до об’єктів фізичного оточення; отримання інформації у найзручніший спосіб та спрощений доступ до цифровізованих та аналогових державних та соціальних послуг; рівні умови участі у всіх сферах життя суспільства; умови та рівні можливості для занять фізичною культурою та спортом, культурного (мистецького) та/або креативного вираження, провадження культурної діяльності; доступ до культурних послуг, культурних цінностей, культурної спадщини та інформації про них; участь у політичних процесах та громадській діяльності; рівні можливості та вільний доступ до освіти; рівні умови та можливості у сфері зайнятості, а також заняття підприємництвом» [1].

Створення безбар'єрного середовища має враховувати, що, за даними соціологічного дослідження щодо ставлення українців до безбар'єрності та інклюзії в суспільстві (2020р.), переважна більшість респондентів вважає, що, в першу чергу, займатися питанням усуненням бар'єрів мають місцеві (79\% зараховують до топ-2) і центральні (66\%) органи влади. Ще 15\% говорять про бізнес, 8\% пропонують активно долучати до процесу громадські організації та звичайних жителів [5].

Ці показники свідчать про певні патерналістські настрої українців щодо вирішення проблем безбар'єрності, тому варто звернути увагу на побудову культури підтримки маломобільних груп з боку самих громадян, на розвиток волонтерства, формування активного міжсекторного партнерства.

На нашу думку, міжсекторне партнерство стає необхідною умовою реалізації завдань Національної стратегії у створенні безбар'єрного простору, що вимагає спільності, взаємної зацікавленості, внеску кожного у спільну справу. Це дозволяє дійти згоди про спільні цінності і принципи, виробити спільні цілі і задачі, заходи та програми діяльності. Саме така практика потрібна наразі для того, щоб долати бар'єри та ізоляцію окремих груп, більш прозоро і відповідально розподіляти ресурси задля вирішення проблем маломобільних груп. Це означає, що саме міжсекторне партнерство розглядається нами як важливий механізм створення нових можливостей i порозуміння в створенні безбар'єрного простору, розвитку інклюзивного діалогу. Основними принципами міжсекторного партнерства $\epsilon$ конструктивна співпраця, раціональність у прийнятті рішень, фандрайзинг, 
використання спільних комунікативних платформ, соціальна відповідальність. Впровадження принципів міжсекторного партнерства при створенні безбар'єрного простору надає можливість досягати забезпечення рівних можливостей кожній людині реалізовувати свої права та робити суспільство більш толерантним та інклюзивним.

Висновки Наведений аналіз методологічних засад дослідження безбар'єрного середовища у публічному управлінні свідчить, що вирішення проблем безбар'єрності полягає в забезпеченні доступності фізичного, соціального, економічного та культурного оточення, охорони здоров'я та освіти, а також інформації та зв'язку, що може сприяти створенню для всіх громадян можливості повною мірою користуватися всіма правами людини та основоположними свободами. Цей обов'язок розглядається нами не тільки як діяльність публічної влади, але й участь громадськості, бізнесу, розвиток поваги до індивідуальності і людського різноманіття та підвищення рівня самосвідомості суспільства.

\section{Лimepamypa:}

1. Національна стратегія із створення безбар'єрного простору в Україні на період до 2030 року. розпорядженням Кабінету Міністрів України від 14 квітня 2021 p. № 366-p. URL: www. https://www.kmu.gov.ua > npas

2. В Киеве появился омбудсмен по правам людей с инвалидностью. Каковы его функции URL: www. https://glavcom.ua/ru/news/v-kieve-poyavilsya-ombudsmen-po-pravam-lyudey-sinvalidnostyu-kakovy-ego-funkcii-738514.html

3. Global Social Mobility Index 2020. World Economic Forum. 2020. URL: http://www3.weforum.org/docs/Global_Social_Mobility_Report.pdf

4. Міністерство соціальної політики України. Особам 3 .. $\quad$ URL: www..https://www.msp.gov.ua > timeline > invalidnist

5. 56\% українців оцінюють рівень інклюзії як низький або дуже ... URL: www. https://www.ukrinform.ua

6. Дрюма О. Безбар'єрне середовище для людей з інвалідністю в Україні: п’ять основних проблем URL: www. https://www.irf.ua > bezbarern...

7. Конвенція про права інвалідів URL: www http://zakon2.rada.gov.ua/laws/show/995_g71

\section{References:}

1. Rozporiadzhennia Kabinet Ministriv Ukrainy "Pro skhvalennia Natsionalnoi stratehii iz stvorennia bezbariernoho prostoru v Ukraini na period do 2030 roku” vid 14 kvitnia 2021 r., № 366-r [Order of the Cabinet of Ministers of Ukraine "On approval of the National Strategy for the creation of barrier-free space in Ukraine for the period up to 2030" from April 14 2021, № 366-r]. zakon.rada.gov.ua. Retrieved from https://www.kmu.gov.ua/npas/pro-shvalennyanacionalnoyi-strategiyi-iz-stvorennya-bezbaryernogo-prostoru-v-ukrayini-na-period-do-t140421 [in Ukrainian].

2. V Kieve poyavilsya ombudsmen po pravam lyudey s invalidnost'yu. Kakovy ego funktsii [An ombudsman for the rights of people with disabilities has appeared in Kiev. What are its functions]. (n.d.). Retrieved from https://glavcom.ua/ru/news/v-kieve-poyavilsyaombudsmen-po-pravam-lyudey-s-invalidnostyu-kakovy-ego-funkcii-738514.html [in Russian].

3. Global Social Mobility Index 2020. (2020). World Economic Forum. www3.weforum.org. Retrieved from http://www3.weforum.org/docs/Global_Social_Mobility_Report.pdf [in English]. 
4. Osobam z invalidnistiu [Persons with disabilities]. www.msp.gov.ua. Retrieved from https://www.msp.gov.ua/timeline/invalidnist.html [in Ukrainian].

5. Kochmar-Tymoshenko, S. (2020). 3/4 ukraintsiv vzhe distaly pereshkody v infrastrukturi mista - opytuvannia [3/4 of Ukrainians have already received obstacles in the city's infrastructure - the poll]. life.pravda.com.ua. Retrieved from https://ife.pravda.com.ua/society/2020/11/26/243174/ [in Ukrainian].

6. Driuma, O. (2013). Bezbarierne seredovyshche dlia liudei z invalidnistiu v Ukraini: piat osnovnykh problem [Barrier-free environment for people with disabilities in Ukraine: five main problems]. www.irf.ua. Retrieved from https://www.irf.ua/bezbarerne_seredovische_dlya_lyudey_z_ invalidnistyu_v_ukraini_pyat_osnovnikh_problem/[in Ukrainian].

7. Konventsiia pro prava osib $\mathrm{z}$ invalidnistiu [Convention on the rights of persons with disabilities].zakon.rada.gov.ua. Retrieved from https://zakon.rada.gov.ua/laws/show/995_g71\#Text [in Ukrainian]. 